\title{
Penggunaan Masker pada Saat Aktivitas Fisik di Saat Pandemi Covid-19
}

\author{
Arif Wicaksono $^{1 *}$, Arina Nurfianti ${ }^{2}$ \\ 1,2 Prodi Kedokteran Fakultas Kedokteran Universitas Tanjungpura Pontianak, Indonesia
}

\section{ARTICLE INFO}

\section{Article history:}

Received September 02, 2021

Revised September 06, 2021

Accepted October 07, 2021

Available online October 25, 2021

Kata Kunci:

Pandemi COVID-19, aktivitas fisik, masker, adaptasi

Keywords:

COVID-19 pandemic, physical activity, masks, adaptation

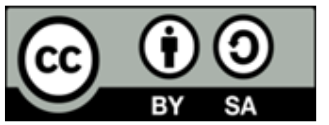

This is an open access article under the CC BY-SA license.

Copyright $\odot 2021$ by Author. Published by Universitas Pendidikan Ganesh

\begin{abstract}
A B S T R A K
Kebijakan untuk mencegah meluasnya penyebaran virus covid-19 berdampak terhadap aktivitas masyarakat. Hal ini menyebabkan aktivitas fisik masyarakat berkurang dan berpengaruh terhadap kekebalan tubuh serta kesehatan masyarakat. Penelitian ini bertujuan untuk mengetahui penggunaan masker oelh masyarakat pada saat aktivitas fisik di saat pandemic covid-19. Jenis penelitian yang digunakan dalam penelitian ini adalah penelitian deskriptif kualitatif. Hal tersebut karena penelitian ini dideskripsikan menggunakan kata-kata tidak menggunakan angka. Pengumpulan data dilakukan dengan observasi. Hasil penelitian ini menunjukkan bahwa masyakarat telah menggunakan masker saat aktivitas fisik. Masyarakat dapat menggunakan masker saat melakukan aktivitas fisik dan hal ini merupakan pilihan bersifat individual yang berhubungan dengan mekanisme adaptasi individu dan bervariasi dibandingkan dengan individu lain.
\end{abstract}

\section{A BS TRAK}

Policies to prevent the spread of the Covid-19 virus have an impact on community activities. This causes the community's physical activity to decrease and affects the immune system and public health. This study aims to determine the use of masks by the public during physical activity during the covid-19 pandemic. The type of research used in this research is descriptive qualitative research. This is because this research is described using words not using numbers. Data collection is done by observation. The results of this study indicate that the community has used masks during physical activities. People can use masks when doing physical activities and this is an individual choice that is related to individual adaptation mechanisms and varies compared to other individuals.

\section{PENDAHULUAN}

Pada tahun 2020 dunia dikejutkan dengan muncul dan menyebarnya wabah yang dikenal dengan covid 19. Covid-19 ini disebabkan oleh oleh Severe Acute Respiratory Syndrome Coronavirus-2 (SARSCoV-2) yaitu virus yang menyerang sistem pernapasan (Putri \& Purwanto, 2020; Susilo et al., 2020). Virus corona pertama kali di temukan di kota Wuhan, Tiongkok (Lee \& Hsueh, 2020; Zhu et al., 2020). Wabah virus ini tidak dapat diabaikan begitu saja karena penularan virus ini cukup signifikan sehingga penyebarannya meluas dengan cepat hingga seluruh negara didunia merasakan dampaknya termasuk Indonesia. Organisasi Kesehatan Dunia (WHO) menyatakan bahwa wabah virus corona sebagai keadaan darurat kesehatan masyarakat hingga mengumumkan bahwa status covid-19 sebagai pandemic. Oleh karenanya seluruh dunia harus segara melakukan upaya pencegahan dan mengatasi dampak dari wabah virus corona. Kebijakan yang dilakukan untuk mencegah semakin meluasnya penyebaran virus corona adalah pembatasan fisik atau physical distancing (Anugrahana, 2020; Prasetya \& Harjanto, 2020; Yunus \& Rezki, 2020). Akibat kebijakan ini telah membawa dampak yang signifikan diberbagai bidang ekonomi, social, pendidikan, dan budaya (Pakpahan \& Fitriani, 2020; Sadikin, A., \& Hamidah, 2020). Pada bidang pendidikan pemerintah mengeluarkan kebijakan pembelajaran daring, yaitu pembelajaran secara online dengan bantuan internet lewat zoom meeting, wa, dan google meet (Anugrahana, 2020; Pratiwi, 2020). Di bidang ekonomi tentu dengan adanya kebijakan berupa pembatasan aktivitas menyebabkan banyak usaha 
yang terpaksa tutup sehingga ekonomi mengalami kemunduran. Pada aspek budaya, banyak pariwisata yang terpaksa tutup, konser ataupun event-event yang melibatkan banyak orang dilarang oleh pemerintah. Adanya kebijakan pembatasan fisik ini menyebabkan aktivitas fisik seseorang menjadi terbatas, karena dilarang untuk keluar rumah kalau memang tidak ada hal yang sangat mendesak. Oleh karenanya masyarakat lebih banyak diam dirumah dan beraktifitas hanya dirumah. Kebijakan-kebijakan yang dikeluarkan oleh pemerintah diharapkan mampu mencegah dan mengatasi penyebaran virus corona. Namun yang terjadi dilapangan, semakin hari jumlah kasus yang terkonfirmasi covid-19 semakin bertambah. Penyebaran langsung COVID-19 adalah melalui droplet dan tidak langsung dan permukaan yang masih mengandung droplet dari orang yang terinfeksi (walaupun belum diperiksa dan tanpa gejala) yang dapat bertahan selama beberapa jam sampai beberapa hari sesuai dengan jenis permukaannya, dan pada udara bebas selama 2-4 jam (Wicaksono \& Nurfianti, 2020). Penyebaran tidak langsung melalui berbagai permukaan dan udara sangat sulit untuk kita ketahui, orang-orang tanpa gejala yang tidak diperiksa atau tidak memeriksakan diri yang tetap menjalankan aktivitas seperti biasa, belum lagi banyak masyarakat yang tidak menerapkan protokol kesehatan dengan baik, seperti tidak menggunakan masker serta tidak mencuci tangan dengan bersih, selain itu masyarakat ketika malas untuk melakukan aktifitas fisi seperti olahraga.

Aktivitas fisik adalah gerakan tubuh yang dengan bantuan kerja otot dan menghasilkan pengeluaran energi untuk beraktifitas (CJ, KE, \& Christenson, 1985). Aktivitas fisik sangat berpengaruh terhadap metabolisme tubuh, kondisi psikologis, serta kesehatan dan kualitas hidup secara menyeluruh terhadap tingkat kesehatan masyarakat (D, A, \& PM, 2018; Suryadinata \& Sukarno, 2019). Aktivitas fisik juga memiliki pengaruh positif pada sistem imun serta berpengaruh dalam menurunkan risiko mengalami penyakit menular seperti infeksi bakteri dan virus, salah satunya virus corona (Ashadi, Mita Andriana, \& Pramono, 2020; JP \& JE., 2018). Aktivitas fisik dapat dilakukan sesuai umur, jenis, dimulai dengan pemanasan terlebih dahulu dengan intensitas ringan-sedang dan direkomendasikan untuk dilakukan di rumah atau sekitar rumah. Aktivitas fisik di luar rumah selama pandemi masih boleh dilakukan dengan mengikuti protokol kesehatan (Wicaksono, 2020). Protokol kesehatan harus selalu dilakukan bersamaan. Menjaga kebersihan tangan dan tubuh, menjaga jarak, dan memakai masker. Ketiganya harus dilakukan semua secara bersamaan, selalu. Tidak boleh terjadi cuci tangan dan memakai masker tetapi tidak menjaga jarak, atau menjaga jarak saja tapi tidak menggunakan masker. Kedisiplinan ini akan sangat mempengaruhi jalannya protokol kesehatan, baik untuk diri sendiri, keluarga, dan masyarakat (Wicaksono \& Nurfianti, 2020). Jika semua masyarakat mentaati dan melaksnakan sesuai dengan protocol kesehatan yang telah ditetapkan maka kemungkinan masyarakat untuk terkana virus ini sangat kecil. Masyarakat akan mendapat manfaat dari olahraga apabila melakukan kegiatan olahraga 150 menit terakhir per minggu (Ashadi et al., 2020). Pentingnya aktivitas fisik pada saat pandemi Covid-19 berhubungan dengan sistem kekebalan tubuh (Arinda, Fajar, Sari, \& Yuliarti, 2021). Banyak sekali cara untuk meningkatkan aktivitas fisik selama pandemic seperti senam aerobic, zumba, yoga, sepeda statis, treadmill, dan lain-lain (Hammami, Harrabi, B., Mohr, \& Krustrup, 2020). Berdasarkan temuan-temuan tersebut, di tengah semakin giatnya penyebaran virus corona masyarakat harus sadar tentang protocol kesehatan, mampu berfikir bijak untuk saling menjaga satu sama lain dengan menghindari hal-hal yang mampu memicu penyebaran virus serta melakukan pencegahan dengan mengkonsumsi makanan yang bergizi dan menajaga kesehatan dengan melibatkan aktivitas fisik yang positif. Penelitian ini bertujuan untk mengetahui bagaimana aktivitas fisik masyarakat selama pandemic covid-19.

\section{METODE}

Jenis penelitian yang digunakan dalam penelitian ini adalah penelitian deskriptif kualitatif. Hal tersebut karena penelitian ini dideskripsikan menggunakan kata-kata tidak menggunakan angka. Telaah literatur bersumber dari buku, jurnal, panduan, surat resmi dan berita terkait protokol kesehatan COVID19 dan aktifitas fisik selama pandemi. Sumber-sumber referensi dikumpulkan dari berbagai sumber terpercaya dari dalam dan luar negeri dari bulan Januari 2020 sampai bulan Agustus 2021. Observasi lingkungan dilakukan saat melakukan aktivitas fisik tim dengan melihat protokol kesehatan yang dilakukan pelaku aktivitas fisik, staf dan pengelola sebelum, saat dan sesudah aktivitas. Observasi penggunaan masker adalah observasi individu pada pelaku aktivitas fisik yang menggunakan masker saat melakukan aktivitas fisik, melihat adaptasi tubuh terhadap pemakaian masker.

\section{HASIL DAN PEMBAHASAN}




\section{Hasil \\ Penggunaan Masker saat Aktivitas Fisik di Rumah/sekitar Rumah}

Aktivitas fisik yang dapat dilakukan di rumah antara lain penguatan otot, senam peregangan, yoga, berjalan statis, bersepeda statis, dan jalan kaki di halaman rumah. Aktivitas fisik direkomendasikan dilakukan di rumah atau di area pribadi sehingga tidak memerlukan kontak dengan orang lain atau pun kerumunan. Pada aktivitas fisik di rumah direkomendasikan untuk tidak menggunakan masker.(Fisiologi, 2020; Resti, 2021).

\section{Penggunaan Masker saat Aktivitas Fisik di Luar Rumah}

Aktivitas fisik yang dilakukan diluar rumah mengharuskan masyakarat untuk mematuhi dan melaksanakan protokol kesehatan seperti mendapatkan informasi terkini di daerah tempat tinggal, memastikan kondisi tubuh baik, menghindari kontak fisik, mencuci tangan dengan air mengalir dan sabun atau membersihkan tangan menggunakan hand sanitizer, membersihkan semua peralatan yang digunakan, menghindari menyentuh mata, hidung, dan mulut, langsung mandi dan mencuci pakaian saat tiba di rumah, dan selalu menggunakan masker merupakan protokol kesehatan standar saat melakukan aktivitas fisik di luar rumah. Berdarkan hasil obserrvasi terdapat penemuan sebagai berikut.

Observasi pada seorang laki-laki berusia 37 tahun yang memilih menggunakan masker saat melakukan aktivitas futsal dan sepak bola didapatkan data sebagai berikut : mekanisme adaptasi berlangsung selama 2-4 menit. Subjek tersebut mengganti masker bedah dengan masker kain khusus olahraga saat sampai di lapangan futsal dan lapangan sepakbola. Subjek melakukan pemanasan dalam kondisi memakai masker. Pada menit kedua subjek merasa sedikit tidak nyaman, terjadi mekanisme rebreathing ekspirasi. Pada menit keempat rasa tidak nyaman masih ada kemudian berangsur menghilang. Subjek melakukan aktivitas futsal dengan rerata waktu 60 menit dalam keadaan menggunakan masker. Masker diganti saat sudah basah karena keringat. Subjek melakukan aktivitas sepakbola dengan rerata waktu 30 menit dalam keadaan menggunakan masker. Masker diganti saat basah dan pernah dalam waktu 30 menit mengganti masker 3 kali karena saat beraktivitas turun hujan. Saat minum atau makan di sela aktivitas, masker dibuka sepenuhnya, menjaga jarak dengan rekan tim lain, dan menggunakan masker kembali saat selesai makan/minum. Observasi pada seorang wanita berusia 35 tahun yang memilih menggunakan masker saat melakukan aktivitas yoga didapatkan data sebagai berikut : mekanisme adaptasi berlangsung selama 5 menit. Subjek mengganti masker bedah dengan masker kain saat berada di studio yoga. Subjek melakukan gerakan-gerakan yoga selama rerata 60 menit dalam kondisi memakai masker. Pada menit awal sampai menit ke 5 subjek merasa agak sesak, setelahnya tidak merasakan gangguan yang berarti. Kedua subjek ini dari awal pandemi sampai saat ini selalu menggunakan masker saat melakukan aktivitas fisik.

Terdapat dua pendapat umum mengenai penggunaan masker saat melakukan aktivitas fisik. Terdapat rekomendasi untuk menggunakan masker dan ada rekomendasi untuk tidak menggunakan masker. Hal ini didasarkan pada efek yang ditimbulkan saat memakai masker saat melakukan aktivitas fisik dan intensitas aktivitas fisik. Intensitas adalah jumlah kekuatan fisik, yang dinyatakan sebagai persentase maksimum yang digunakan tubuh dalam melakukan suatu aktivitas. Intensitas terbagi menjadi intensitas ringan, sedang, dan berat. Terdapat beberapa cara untuk menilai intensitas. Cara pertama yang paling banyak digunakan adalah dengan dengan denyut jantung maksimal (DJM). Tingkat intensitas aktivitas fisik yang diukur dengan DJM terbagi menjadi : Ringan : 40-54\% DJM, Sedang: 55-69\% DJM, dan Tinggi : $=70 \%$ DJM. Terdapat satu cara yang lebih sederhana untuk menentukan intensitas, dan dapat digunakan secara mudah untuk menilai aktifitas fisik yaitu tes bicara. Tingkat intensitas aktivitas fisik yang diukur dengan tes bicara terbagi menjadi : Ringan : dapat berbicara dan bernyanyi dengan lancer, Sedang: dapat berbicara, tidak dapat bernyanyi, dan tinggi : tidak dapat berbicara, nafas terengah-engah. Penentuan intensitas aktivitas fisik yang direkomendasikan adalah menggunakan DJM. Kita melakukan penghitungan DJM selama 60 detik penuh/1 menit. Selalu perhatikan intensitas aktivitas fisik yang dilakukan sesuai usia dan direkomendasikan intensitas ringan-sedang.

Aktivitas fisik di luar rumah dapat dikategorikan menjadi 2 yaitu risiko sedang dan risiko tinggi. Risiko sedang adalah dilakukan di tempat umum sendiri, di tempat umum dengan keluarga (dengan jumlah paling banyak 4 orang), dan menggunakan peralatan sendiri. Risiko tinggi adalah di tempat umum dan berkelompok, di tempat umum bersama orang lain yang bukan keluarga, menggunakan peralatan bergantian, dan di tempat tertutup. Aktivitas fisik yang dilakukan sendiri jika berdiam di satu tempat harus menjaga jarak 1,5 meter dengan orang lain. Aktivitas fisik berjalan harus menjaga jarak 5 meter dengan orang lain. Aktivitas fisik berlari harus menjaga jarak 10 meter dengan orang lain dan bersepeda harus menjaga jarak 20 meter dengan orang lain. Hal ini dilakukan dengan protokol-protokol kesehatan standar, dan menggunakan masker. Aktivitas fisik yang dilakuan di tempat umum dengan keluarga 
direkomendasikan untuk tidak ada kontak fisik, intensitas ringan-sedang, memenuhi protokol-protokol kesehatan standar, dan menggunakan masker

Melakukan aktivitas fisik di pusat kebugaran harus memastikan kondisi tubuh sehat sebelumnya, jika ada gejala seperti demam, batuk, pilek, nyeri tenggorokan dan/atau sesak nafas, disarankan untuk tidak pergi ke pusat kebugaran. Disarankan mandi terlebih dahulu sebelum berlatih di pusat kebugaran, tidak melakukan kontak, dan bersentuhan langsung dengan orang lain. Direkomendasikan melakukan latihan intensitas sedang dan wajib memakai masker di area pusat kebugaran. Mengganti masker yang dipakai dari luar. Masker yang digunakan saat keluar rumah sampai pusat kebugaran, dibuang sesuai ketentuan, diganti masker baru selama berada di pusat kebugaran dan melakukan aktivitas fisik, dan setelah selesai aktivitas dibuang di pusat kebugaran tersebut. Masker baru dipergunakan sebagai pengganti untuk perjalanan pulang. Penggunaan alat olahraga di pusat kebugaran lazimnya dipakai bergantian oleh banyak orang dan aktivitas di ruangan yang diisi oleh beberapa orang dan kemungkinan berdekatan merupakan kondisi risiko tinggi terjadinya penularan infeksi COVID-19, belum lagi data tentang pengelola, staf, dan orang yang datang apakah semua sudah diperiksa dan semua negatif COVID19.

Melakukan aktivitas fisik dengan yang bukan anggota keluarga menaikkan risiko penularan karena tidak ada yang tahu bagaimana protokol kesehatan dilakukan di masing-masing rumah yang lain, dan apakah keluarga lain itu pernah diperiksa atau pernah menjadi kasus konfirmasi. Tempat umum dapat berupa lapangan, lintasan, atau lapangan indoor yang seharusnya dilakukan protokol kesehatan pula untuk para pengelola, pekerja, orang yang datang, dan ruangan-ruangan serta area-area di sekitarnya. Aktivitas fisik tim banyak yang merupakan aktifitas fisik kontak, seperti sepak bola, futsal, dan bola basket yang memungkinkan terjadinya kontak antara pemain dalam satu tim, antara pemain tim dengan tim lawan, dan antara pemain dan bola. Protokol kesehatan untuk atlet sudah lebih baik karena atlet memiliki program latihan khusus, memiliki tim medis khusus, dan untuk prestasi. Artikel ini lebih pada aktivitas fisik umum untuk masyarakat terkait kegemaran mereka dan kemungkinan yang masih dapat dilakukan dengan mempertimbangkan kondisi sekitar dan protokol kesehatan di masa pandemi ini.

\section{Pembahasan}

Penggunaan masker merupakan salah satu cara mencegah transmisi COVID-19 bersama dengan beberapa protokol kesehatan lain. Penggunaan masker dilihat secara satu variabel saja sangat menarik. Masker dapat memberikan fungsi proteksi, menjadi penyaring untuk bakteri dan virus, termasuk droplet yang mengandung virus. Pemakaian masker juga dapat menyebabkan sesak nafas karena menghirup udara yang sudah diekspirasi sebelumnya, serta masuknya keringat ke hidung atau mulut (Thendiono, 2021). Perubahan terjadi pada tingkat metabolisme sel, terjadi perbedaan antara respirasi biasa tanpa masker dan respirasi saat menggunakan masker. Sirkulasi udara inspirasi dan ekspirasi yang tertutup akibat menggunakan masker akan menyebabkan udara ekspirasi akan terhirup kembali (rebreathing), sehingga meningkatkan konsentrasi karbondioksida , memperburuk metabolisme anaerob, dan akhirnya meningkatkan intensitas keasaman pada lingkungan sel dan terbentuk asam laktat berlebihan. Kondisi ini bisa mengakibatkan gejala seperti rasa tidak nyaman, lelah, pusing, nyeri kepala, sesak napas, kelemahan otot, hingga penurunan kesadaran.

Penggunaan masker dapat memengaruhi oksigen dan karbondioksida sehingga dapat meningkatkan denyut jantung dan tekanan darah secara eksponensial, meningkatkan tekanan pada aorta dan ventrikel kiri, yang selanjutnya memicu cardiac overload dan coronary demand sehingga dikompensasi dengan penyesuaian respiratory load. Terdapat mekanisme kompensasi dan adaptasi tubuh pada orang yang sehat, tetapi menurun dan berbeda pada orang dengan penyakit kronis (Thendiono, 2021). Hipoksia, hiperkapnia, tekanan pada sistem jantung-paru, hingga dapat mengganggu irama jantung adalah hal-hal yang dapat terjadi saat melakukan aktivitas fisik menggunakan masker. Terdapat pendapat yang tidak merekomendasikan penggunaan masker dalam beraktivitas fisik dengan intensitas apapun, lebih menyarankan menjaga jarak (tidak memakai masker) jika melakukan aktivitas fisik di luar dan merekomendasikan untuk melakukan aktivitas di dalam rumah saja tanpa menggunakan masker (Chandrasekaran \& Fernandes, 2020). Penggunaan masker saat melakukan aktivitas fisik masih diperdebatkan. Banyak hal yang akhirnya memengaruhi penggunaan masker ini sampai ke tingkat individu. Individu satu dan individu lainnya dapat memilih untuk menggunakan masker atau tidak berdasarkan pertimbangan-pertimbangan ilmiah yang berfokus pada diri satu individu dengan tetap mematuhi protokol kesehatan.

Masyarakat hendaknya meningkatkan kesadaran dengan mematuhi protocol kesehatan. bila sedang melakukan aktifitas fisik diluar ruangan atau di tempat umum agar menggunakan masker dengan baik dan benar, selalu menjaga kebersihaan (Beiu, Mihai, Popa, Cima, \& Popescu, 2020; Greenhalgh, Schmid, Czypionka, Bassler, \& Gruer, 2020). Adapaun langkah-langkah yang dapat kita lakukan agar 
beraktifitas diluar lebih nyaman adalah pertama kita harus mengetahui kondisi kesehatan kita, yaitu dengan melakukan pemeriksaan swab PCR merupakan diagnosis untuk mengetahui kita terinfeksi COVID19 atau tidak. Hasil pemeriksaan negatif berarti kita sehat atau tidak terinfeksi COVID-19 dan dapat melakukan aktivitas fisik, kedua, mengetahui sebaran kasus di lingkungan kita. Dengan mengetahui status daerah tempat kita tinggal atau daerah yang akan kita tuju akan memantapkan kita untuk melakukan aktivitas fisik, di rumah, di sekitar rumah atau tempat umum yang jauh dari rumah, ketiga, mengetahui perilaku masyarakat sekitar kita terhadap protokol kesehatan COVID-19. Hal ini akan menyadarkan kita mengenai lingkungan kita, apakah mendorong ke arah ketaatan terhadap protokol kesehatan atau tidak. Hal ini dapat pula untuk menjadi pemicu kita untuk tetap melakukan protokol kesehatan sebaik-baiknya untuk diri kita sendiri dan orang-orang terdekat kita. Keempat, menentukan aktivitas fisik yang akan dilakukan apakah di dalam rumah atau di luar rumah, kelima, menentukan intensitas aktivitas fisik yaitu intensitas ringan atau sedang. Keenam, selalu menggunakan masker untuk aktivitas fisik yang dilakukan di luar rumah (Park, Kim, \& Lee, 2020; Vancini et al., 2021) dengan memperhatikan intensitas melalui tes bicara. Ketujuh, membawa beberapa masker saat meakukan aktivitas fisik, ini bertujuan agar saat melakukan aktifitas diluar kita dapat mengganti masker dengan masker baru saat perpindahan tempat, dari rumah ke tempat aktivitas, dari tempat aktivitas ke rumah.

Masker dapat diganti jika merasa terlalu sesak dan jika basah. Pemakaian masker yang terlalu ketat saat aktivitas fisik dapat menimbulkan rasa tidak enak dan sesak. Adanya cairan seperti keringat yang tertahan di masker, masuk ke hidung dan mulut akan menambah kesulitan dalam bernafas. Tubuh kita memiliki mekanisme adaptasi terhadap pemakaian masker pada saat melakukan aktivitas fisik. Adaptasi yang terjadi pada pemakaian masker akan berbeda-beda tiap individu (Epstein et al., 2020; Shurlock et al., 2021). Walaupun masih ada perbedaan pendapat tentang pemakain masker pada aktivitas fisik. Pada masa pandemic covid-19 masyarakat harus mampu menjaga kesehatan dengan menerapkan pola hidup sehat, selalu mematuhi ptotokol kesehatan serta aktif untuk melakukan aktivitas fisik dari yang sederhana hingga yang berat. Karena dengan melakukan aktivitas fisik seperti olahraga ringan akan mampu menjaga kekebalan tubuh sehingga terhindar dari virus dan bakteri. Pendapat ini sejalan dengan penelitian (Nurhadi \& Fatahillah, 2020) yang menunjukkan bahwa aktivitas fisik yang dilakukan secara teratur memiliki efek yang luar biasa terhadap kesehatan. Peningkatan pengetahuan tentang perilaku hidup bersih dan sehat yaitu melakukan cuci tangan dengan sabun atau hanzaniter, menggunakan masker dan tidak berkemurum atau social distancing sangat diperlukan guna mencegah penularan semakin meluas (Setiyowati, Juliasih, \& Hanik, 2021). Selajan dengan penelitian oleh (Kurniati, Triana, Yulianty, Rosana, \& Salsabilah, 2021) yang menunjukkan bahwa edukasi berkelanjutan diperlukan untuk menjaga ketaatan dalam melaksanakan protokol kesehatan 3M (Mencuci Tangan, Memakai masker, Menjaga jarak).

\section{SIMPULAN DAN SARAN}

Menggunakan masker saat melakukan aktivitas fisik merupakan pilihan yang bersifat individual dan berhubungan dengan mekanisme adaptasi individu tersebut yang akan bervariasi jika dibandingkan dengan individu yang lain. Pengetahuan tentang kesehatan diri, lingkungan, dan tempat melakukan aktivitas fisik menjadi dasar penggunaan masker. Aktivitas fisik di luar ruangan dengan memakai masker direkomendasikan dengan intensitas ringan-sedang. Gunakan masker yang nyaman, melindungi, dan tidak terlalu ketat. Saat merasa sesak, makan atau minum boleh melepas masker. Dianjurkan untuk membawa beberapa masker saat melakukan aktivitas fisik untuk melakukan pergantian masker saat masker yang dipakai dalam keadaan basah.

\section{DAFTAR RUJUKAN}

Anugrahana, A. (2020). Hambatan, Solusi dan Harapan: Pembelajaran Daring Selama Masa Pandemi Covid-19 Oleh Guru Sekolah Dasar. Scholaria: Jurnal Pendidikan Dan Kebudayaan, 10(3), 282-289. https://doi.org/10.24246/j.js.2020.v10.i3.p282-289.

Arinda, D. F., Fajar, W. I., Sari, D. M., \& Yuliarti. (2021). Aktivitas Fisik, Perilaku Kesehatan Dan Gizi Di Masa New Normal Pada Pegawai Di Indonesia. JAKAGI: Jurnal Pangan Kesehatan Dan Gizi, 1(2), 9 - 19. Retrieved from http://journal.binawan.ac.id/JAKAGI/article/view/154/131.

Ashadi, K., Mita Andriana, L., \& Pramono, B. A. (2020). Pola aktivitas olahraga sebelum dan selama masa pandemi covid-19 pada mahasiswa fakultas olahraga dan fakultas non_olahraga. Jurnal SPORTIF : Jurnal Penelitian Pembelajaran, 6(3), 713-728. https://doi.org/10.29407/js_unpgri.v6i 3.14937.

Beiu, C., Mihai, M., Popa, L., Cima, L., \& Popescu, M. N. (2020). Frequent Hand Washing for C ovid-19 Prevention Can Cause Hand Dermatitis: Management Tips. Cureus, 12(4), 1-7. https://doi.org/10.7759/cureus.7506. 
Chandrasekaran, B., \& Fernandes, S. (2020). Exercise with Facemask; Are we Handling a Devil's Sword? Medical Hypotheses, 144(June). https://doi.org/https:// doi.org/10.1016/j.mehy.2020.110002.

CJ, C., KE, P. G., \& Christenson. (1985). Physical activity, exercise, and physical fitness: Definitions and distinctions for health-related research. Public Health Rep., 100, 126-31.

D, T., A, T., \& PM, G. (2018). Physical Activity, Inactivity, and Sedentary Behaviors: Definitions and Implications in Occupational Health. Public Health, 6, 288.

Epstein, D., Korytny, A., Isenberg, Y., Marcusohn, E., Zukermann, R., Bishop, B., ... Miller, A. (2020). Return to Training in the COVID-19 Era: The Physiological Effects of Face Masks during Exercise. Scandinavian Journal of Medicine and Science in Sports, 1-6. https://doi.org/10.1111/sms.13832.

Fisiologi, D. (2020). Mengapa harus Tetap Beraktivitas Fisik di tengah Pandemi COVID-19? Universitas Gajah Mada. Yogyakarta: Fakultas Kedokteran, Kesehatan Masyarakat, dan Keperawatan Universitas Gadjah Mada.

Greenhalgh, T., Schmid, M. B., Czypionka, T., Bassler, D., \& Gruer, L. (2020). Face masks for the public during the covid -19 crisis. BMJ, 369(1435), 1-4. https://doi.org/10.1136/bmj.m1435.

Hammami, A., Harrabi, B., Mohr, M., \& Krustrup, P. (2020). Managing Sport and Leisure Physical activity and coronavirus disease 2019 (COVID-19): specific recommendations for home- based physical training. Managing Sport and Leisure, O(0), 1-6. https://doi.org/10.1080/23750472.2020. 1757494.

JP, C., \& JE., T. (2018). Debunking the Myth of Exercise_Induced Immune Suppression: Redefining the Impact of Exercise on Immunological Health Across the Lifespan. Front Immunol, 9, 648.

Kurniati, A., Triana, D., Yulianty, M. E. P., Rosana, E., \& Salsabilah, N. T. (2021). Sosialisasi Pemakaian Masker d an Pembagian Masker Dalam Rangka Pemutusan Rantai Penularan Covid -19 di Kota Bengkulu. Dharma Raflesia Jurnal Ilmiah Pengembangan Dan Penerapan IPTEKS, 19(1), 82-90. https://doi.org/10.33369/dr.v19i1.13763.

Lee, P.-I., \& Hsueh, P.-R. (2020). Lee, P. I., \& Hsueh, P. R. (2020). Emerging Threats From Zoonotic Coronaviruses-From SARS And MERS To 2019-Ncov. Journal of Microbiology, Immunology and Infection., 53(3), 365-367. https://doi.org/10.1016/j.jmii.2020.02.001.

Nurhadi, J. Z. L., \& Fatahillah. (2020). Pengaruh Pandemi Covid-19 Terhadap Tingkat Aktivitas Fisik Pada Masyarakat Komplek Pratama, Kelurahan Medan Tembung. Jurnal Health Sains, 1(5), 294-298. https://doi.org/10.46799/jhs.v1i5.52.

Pakpahan, R., \& Fitriani, Y. (2020). Analisa Pemafaatan Teknologi Informasi Dalam Pemeblajaran Jarak Jauh Di Tengah Pandemi Virus Corona Covid-19. JISAMAR (Journal of Information System, Applied, Management, Accounting and Researh), 4(2), 30-36.

Park, S., Kim, B., \& Lee, J. (2020). Social Distancing and Outdoor Physical Activity During the COVID-19 Outbreak in South Korea: Implications for Physical Distancing Strategies. Asia-Pacific Journal of Public Health, 1-3. https://doi.org/10.1177/1010539520940929.

Prasetya, T. A., \& Harjanto, C. T. (2020). Pengaruh mutu pembelajaran online dan tingkat kepuasan mahasiswa terhadap hasil belajar saat pandemi Covid19. Pendidikan Teknologi Dan Kejuruan, 17(2), 188-197.

Pratiwi, E. W. (2020). Dampak Covid-19 Terhadap Kegiatan Pembelajaran Online Di Perguruan Tinggi Kristen Di Indonesia. Perspektif Ilmu Pendidikan, 34(1), 1-8. https://doi.org/10.21009/pip.341.1.

Putri, R. S., \& Purwanto, D. (2020). (2020). Impact of the COVID-19 pandemic on online home learning: An explorative study of primary schools in Indonesia. International ,. Journal of Advanced Science and Technology, 29(5), 4809-4818.

Resti, N. W. (2021). Olahraga di Masa Pandemi COVID-19. Jakarta: Kementerian Pendidikan dan Kebudayaan.

Sadikin, A., \& Hamidah, A. (2020). Pembelajaran Daring di Tengah Wabah Covid-19. Biodik, 6(2), 109-119. https://doi.org/10.22437/bio.v6i2.9759.

Setiyowati, E., Juliasih, N. N., \& Hanik, U. N. (2021). Sosialisasi Peningkatan Perilaku Hidup Bersih Sehat ( PHBS) Sebagai Upaya Memutus Rantai Penularan Virus Corona dalam Situasi Pandemi Covid -19. Madaniya, 2(2), 129-136. https://doi.org/10.53696/27214834.65.

Shurlock, J., Muniz-Pardos, B., Tucker, R., Bachl, N., Papadopoulou, T., Holloway, G., ... Pitsiladis, Y. P. (2021). Recommendations for Face Coverings while Exercising During the COVID-19 Pandemic. Sports Medicine - Open, 7(1). https://doi.org/10.1186/s40798-021-00309-7.

Suryadinata, R. V., \& Sukarno, D. A. (2019). Pengaruh Aktivitas Fisik Terhadap Risiko Obesitas Pada Usia Dewasa. The Indonesian Journal of Public Health, 14(1), 104-114. https: //doi.org/10.20473/ijph.v14i1.2019.104-114.

Susilo, A., Rumende, C. M., Pitoyo, C. W., Santoso, W. D., Yulianti, M., Herikurniawan, H., ... Yunihastuti, E. (2020). Coronavirus Disease 2019: Tinjauan Literatur Terkini. Jurnal Penyakit Dalam Indonesia, 
7(1), 45. https: //doi.org/10.7454/jpdi.v7i1.415.

Thendiono, E. (2021). Dampak Penggunaan Masker saat Olahraga di Era Pandemi COVID-19. Jakarta: Alomedika.

Vancini, R. L., Andrade, M. S., Nikolaidis, P. T., Knechtle, B., Rosemann, T., Viana, R. B., \& Lira, C. A. B. de. (2021). COVID-19: It's Still Time for Health Professionals, Physical Activity Enthusiasts and Sportive Leagues not to Let Guard Down. Sport Medicine and Health Science, 3, 49-53. https://doi.org/https://doi.org/10.1016/j.smhs.2021.01.002.

Wicaksono, A. (2020). Aktivitas Fisik Yang Aman Pada Masa Pandemi Covid-19. Jurnal Ilmu Keolahragaan Undiksha, 8(1), 10-15. https://doi.org/10.23887/jiku.v8i1.28446.

Wicaksono, A., \& Nurfianti, A. (2020). Penyakit Virus Korona-19. Pontianak: IAIN Pontianak Press.

Yunus, N. R., \& Rezki, A. (2020). Kebijakan pemberlakuan lockdown sebagai antisipasi penyebaran corona virus Covid-19. SALAM: Jurnal Sosial Dan Budaya Syar-I, 7(3), $227 \quad$ - 238. https: //doi.org/10.15408/sjsbs.v7i3.15083.

Zhu, N., Zhang, D., Wang, W., Li, X. Yang, B., Song, J., \& Tan, W. (2020). A Novel Coronavirus from Patients with Pneumonia in China, 2019. The New England Journal of Medicine, 382(8), 727-733. https://doi.org/10.1056/NEJMoa2 001017. 